\title{
Ulva australis as a tool for monitoring metal-polluted estuarine system; spatial and temporal considerations
}

\author{
Farias D.R. ${ }^{1}{ }^{*}$, Hurd C.L. ${ }^{2}$, Eriksen R.S. ${ }^{3,4}$ and Macleod C.K. ${ }^{1}$ \\ ${ }^{1}$ Institute for Marine \& Antarctic Studies - Fisheries, Aquaculture \& Coasts (IMAS - FAC), University of Tasmania, Nubeena Crescent, \\ Taroona, 7053, Tasmania, Australia \\ ${ }^{2}$ Institute for Marine \& Antarctic Studies (IMAS), University of Tasmania, 20 Castray Esplanade, Battery Point, Hobart 7004, Tasmania, \\ Australia \\ ${ }^{3}$ Antarctic Climate \& Ecosystem CRC Private Bag 80, UTAS, Hobart, 7001, Australia \\ ${ }^{4}$ CSIRO Oceans \& Atmosphere, Castray Esplanade Battery Point, Hobart 7004, Australia \\ Received: 23/02/2018, Accepted: 13/07/2018, Available online: 26/09/2018 \\ *to whom all correspondence should be addressed: e-mail: D.FariasAqueveque@utas.edu.au \\ https://doi.org/10.30955/gnj.002638
}

\begin{abstract}
This study investigated temporal and spatial patterns of heavy metal content in Ulva australis. Samples were collected from the Derwent Estuary, Tasmania, Australia, over 3 years (2013-2015) at locations where historically arsenic, cadmium, lead and zinc were high in sediments and seawater. Zinc and lead content were high in $U$. australis at all sampling times, with levels consistent with the spatial distribution of metal within the system. Zinc in Ulva varied seasonally $\left(4.8-320.7 \mathrm{mg} \cdot \mathrm{kg}^{-1}\right)$, but lead did not. Zinc and lead were highest in the middle-upper estuary, close to the zinc smelter, where seawater concentrations were higher. The results suggest that spatial variation of metal content in Ulva is a reflection of variability in the seawater, which in turn indicates that $U$. australis could be used for monitoring the effects of metals in estuarine systems, and that $U$. australis could be a useful addition to existing management strategies.
\end{abstract}

Keywords: Biological indicators, biomonitoring, contamination, macroalgae, seasonal variability, Ulva.

\section{Introduction}

Metal pollution in aquatic environments is a worldwide concern. Contamination of estuaries and coastal zones is increasing, and consequently, this may have detrimental effects on the flora and fauna in those systems (Lionetto et al., 2012; Kennish, 2002). Biological monitoring or biomonitoring is one way to obtain information on the potential effects of metals pollutants (Zhou et al., 2008), and a better understanding of the ecological condition of the environment (Campbell, 2002). However, for biomonitoring to be effective, reliable indicators of pollution are needed (Conti et al., 2002); a suitable bioindicator can provide important information on the ecological effect of heavy metal loading in the surrounding environment (Rainbow, 1995; Rainbow and Phillips, 1993; Zhou et al., 2008; Conti et al., 2002).
Urbanised estuaries are often affected by a wide range of anthropogenic perturbations including metal contamination (Kennish, 2002), and this can result in major ecological changes in the system (O'Leary and Breen, 1997; Bryan et al., 1985; Ho, 1984; Coughanowr et al., 2015; Bryan and Langston, 1992). Monitoring of such estuaries often relies on a combination of both chemical (seawater and sediment) and biological measures. Whilst, chemical measures of contaminants levels in seawater can be very precise (Campbell, 2002), they can only offer a snapshot of the conditions at the time of sampling. Sediments, while more temporally stable, are highly heterogeneous and as such can vary widely with depth or sediment type. Consequently, biota may offer a better predictor of overall ecosystem health, as they will provide both a specific understanding of biological uptake and its impacts together with an integrated indication of environmental conditions over time (Holt and Miller, 2011).

Understanding the temporal and spatial variability of the total metals loads within a system is important, but it is also important to understand the bioavailability (the proportion that is available for uptake and accumulation) and as such biomonitoring programs are essential (Rainbow, 1995). Spatial and temporal assessment can provide accurate information on episodic discharges (i.e. industrial discharge) and how these might affect the system, as well as information on the effect of changes in natural and biological processes (i.e. estuarine-scale changes). Understanding how metal loads vary naturally in a chosen bioindicator is essential baseline information if we are to distinguish the effects of anthropogenic inputs (Rainbow, 1993), and is in fact a specified pre-requisite for recommending a bioindicator species for biomonitoring programs.

This is a developing field of research but there are some cosmopolitan bioindicators of metal pollution (i.e. invertebrates and seaweeds), which have already been 
shown to accumulate metals and provide time-integrated measurements of pollution in aquatic systems (Rainbow and Phillips, 1993). Seaweeds are often used, and have been recommended by a number of authors as valuable bioindicators of metal pollution (Rainbow, 1995; Rainbow and Phillips, 1993). They have a number of attributes which make them particularly suitable as bioindicators. In particular, many species show a high tolerance to metal pollution and, being static, they will reflect the conditions at a given location and are easy to sample (Zhou et al., 2008).

However, the ability of seaweeds to take up metals can be influenced by biological factors, such as growth rate and seasonal die backs (Malea and Haritonidis, 1999b), but also take into account broader seasonal changes in environmental conditions that might confound metal uptake. Seasonal patterns are dependent not only on the seaweed species, but can also be affected by the particular metal of interest and its concentration, the metal input source and any episodic considerations for that input and, of course the season (Malea et al., 1995; Brown et al., 1999; Riget et al., 1995). Consequently, when employing seaweeds as a tool for biomonitoring, it is important to understand how all of these factors might influence the response (i.e. metal uptake rate and total load) of any chosen species (Riget et al., 1995). Green seaweeds, such as members of the order Ulvales, are often used in metal biomonitoring investigations (Brown et al., 1999), mainly because they are widespread in many systems and have also been shown to take up metals in high concentrations. Ulva lactuca and $U$. rigida are very well established as bioindicators of metal pollution (Ho, 1990; Favero et al., 1996; Malea and Haritonidis, 2000).

The Derwent Estuary in Tasmania, Australia, is a highly metal-polluted system (Bloom and Ayling, 1977) with zinc $(\mathrm{Zn})$ being the most significant contaminant, particularly in the middle estuary (see in Chapter 2, figure 2.2, 2.3 and 2.4), due to inputs from a refinery (Coughanowr et al., 2015). The Derwent Estuary Program (DEP) has actively monitored the estuary for the past 15 years; with water column metals being assessed at a number of fixed points throughout the estuary regularly throughout the year. Two detailed surveys of sediment metal concentrations having been undertaken (Coughanowr et al., 2015; Whitehead et al., 2010) together with a number of independent surveys assessing metal loads in biota. The DEP monitoring program and other research has also shown that arsenic (As), cadmium (Cd) copper (Cu), lead $(\mathrm{Pb})$ and $\mathrm{Zn}$ are all present at elevated concentrations in sediments (Coughanowr et al., 2015; Bloom and Ayling 1977; Wood et al., 1992), shellfish (Bloom and Ayling, 1977; Eustace, 1974) and fish (Verdouw et al., 2010; Dix et al., 1975; Ratkowsky et al., 1975; Langolis et al., 1987; Eustace, 1974). However, there is no information on the content of heavy metals in seaweeds in the Derwent. However, there is no information on the content of heavy metals in seaweeds in the Derwent. This study used Ulva australis, to characterise the spatial and temporal changes in zinc content within the estuary and examine the effectiveness of this species as a tool for monitoring.

\section{Methods}

\subsection{Study area}

Eight study sites were selected to reflect different metal loads and sources of pollution, i.e. levels of industrial discharge, sewage treatment levels, and heavy metal concentrations (Fig. 1). The estuary was divided into four regions where $U$. australis is located defined as follows: middle-upper (PWB and $\mathrm{SB}, n=2$ ), middle-lower estuary (KB, TRA, LASB, $n=3$ ), and lower estuary (TAR, K, BB, $n=3$ ).

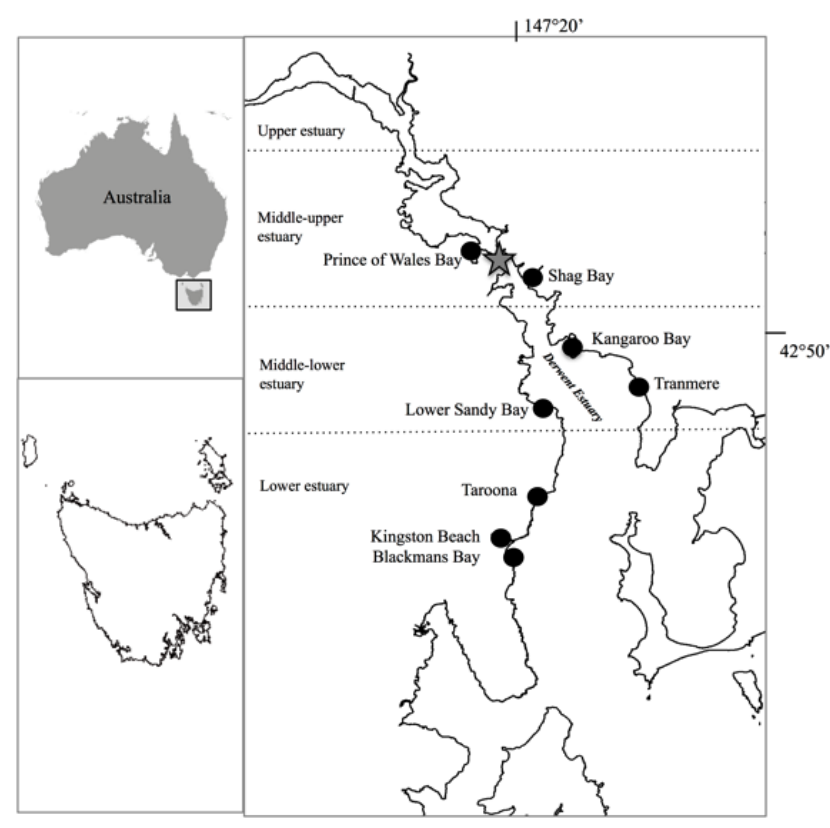

Figure 1. Study area and sampling sites in the Derwent Estuary, Tasmania, Australia on results of the spatial analysis undertaken in the present study. Grey star indicates Zinc smelter (historic source of metal contamination)

\subsection{Field collections}

$U$. australis samples $(n=3)$ were collected from all study sites every three months from October (Spring) 2013 to October (Spring) 2015. Approximately $50 \mathrm{~g}$ of $U$. australis was collected from intertidal areas at low tide. Metal analysis was undertaken as per methods described by Farias et al. (2017). The Derwent Estuary Program (DEP) provided monthly data for surface water $10.1 \mathrm{~m}$ depth) zinc concentration $\left(\mu \mathrm{g} \cdot \mathrm{L}^{-1}\right)$ for the middle estuary study sites (PWB: Princes of Wales Bay, SB: Shag Bay, KB: Kangaroo Bay, TRA: Tranmere, LSB: Lower Sandy Bay). All water and seaweed samples were analysed at Analytical Services Tasmania (AST).

\subsection{Statistical analysis}

Inter-annual differences were assessed between spring 2013 and spring 2015, using a general linear mixed model (GLMM) with area as random effect, year as factor, and gamma distribution. Where this showed a significant interaction, pairwise contrasts were undertaken using a Least-Square Means (Ismeans) package (Lenth and Hervé, 
2015), with Bonferroni adjustment. Seasonal variability was also analysed using GLMM, with area as random effect, year as factor, season as fixed effect, a gamma distribution and restricted suite of post-hoc multiple contrasts using the Least-Square Means (Ismeans) package (Lenth and Hervé, 2015) and Bonferroni adjustment. Seasonal Zn variability in seawater was assessed using a GLMM with a gamma distribution. All GLMM analyses were performed in $\mathrm{R}$ with significance set at alpha $=0.05$ ( $\mathrm{R}$ Core Team, 2013).

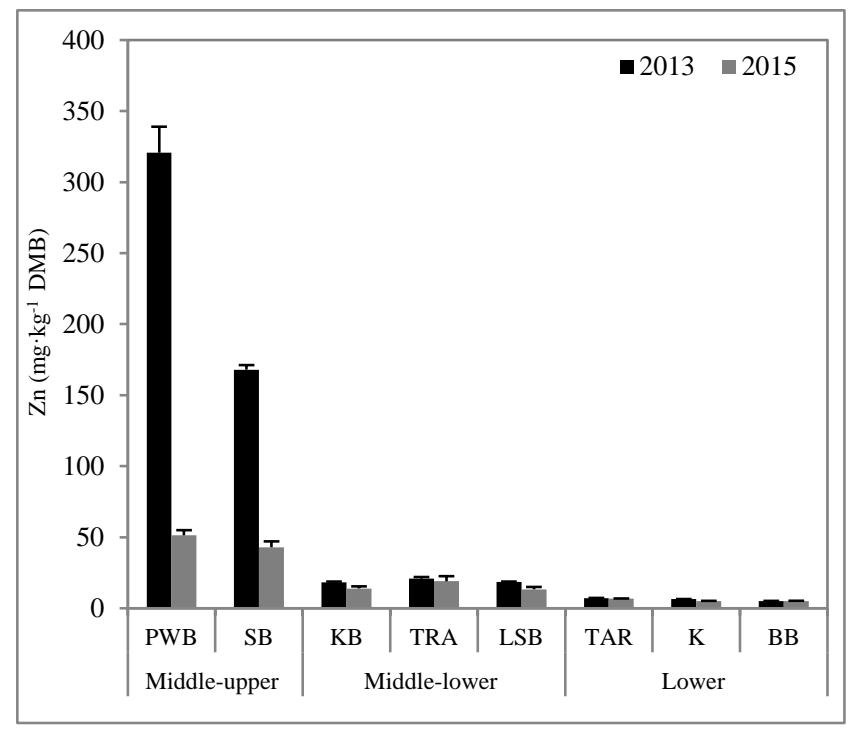

Figure 2. Inter-annual zinc ( $\mathrm{Zn})$ content $\left(\mathrm{mg} \cdot \mathrm{kg}^{-1} \mathrm{DMB}\right)$ in Ulva australis from sites in the Derwent Estuary in Spring 2013 and Spring 2015. Metal levels are expressed as mean ( \pm SE). PWB: Princes of Wales Bay, SB: Shag Bay, KB: Kangaroo Bay, TRA: Tranmere, LSB: Lower Sandy Bay, TAR: Taroona, K: Kingston Beach and BB: Blackmans Bay. Note different scales on $y$-axis

\section{Results}

\subsection{Inter-annual variability}

Total $\mathrm{Zn}$ in $U$. australis content differed markedly between years; in 2013, mean $\mathrm{Zn}$ content was $320.7 \pm 18.3 \mathrm{mg} \cdot \mathrm{kg}^{-1}$, whereas in spring 2015 levels were considerably lower $\left(\mathrm{Zn}=76.5 \pm 1.4 \mathrm{mg} \cdot \mathrm{kg}^{-1}\right)$ (Fig. 2).

\subsection{Seasonal variability}

Zn content varied seasonally ( $p<0.05, F=8.076$, df $=3$ ) and spatially ( $p<0.05, F=24.3439, d f=2)$. Seasonal changes were most pronounced in the middle-upper estuary (Table 1). Metal levels were relatively consistent over time, except in winter 2015, when Zn levels increased in the middle-upper estuary. The highest $\mathrm{Zn}$ levels occurred in the middle-upper estuary in spring 2013, and there was a clear spatial gradient in every season.

There was a strong interaction between season and region ( $p<0.05, F=4.0979$, $d f=6$ ). Post-hoc analysis suggested that this was due to plants from the middle-upper estuary having a much higher $\mathrm{Zn}$ content $\left(244.3 \pm 108.0 \mathrm{mg} \cdot \mathrm{kg}^{-1}\right)$ compared to the middle-lower estuary $\left(42 \pm 27.2 \mathrm{mg} \cdot \mathrm{kg}^{-1}\right)$ and the lower estuary $\left(15.5 \pm 7.3 \mathrm{mg} \cdot \mathrm{kg}^{-1}\right)$ in all seasons $(p<0.05, \mathrm{df}=5)$. This suggests that seasonal patterns are region-specific. Zn content was significantly higher in the middle-upper estuary in summer and spring, than in autumn or winter (Table 1). However, in autumn and winter, there were still clear spatial differences in $\mathrm{Zn}$ content in $U$. australis between the middle-upper and the lower estuary $(p<0.05, d f=5)$. There was no significant difference in $\mathrm{Zn}$ levels between the middle-lower and the lower estuary ( $p>0.05)$ in any season.

Table 1. Zinc (Zn) concentration in surface water $\left(\mu \mathrm{g} \cdot \mathrm{L}^{-1}\right)$ and Ulva australis $\left(\mathrm{mg} \cdot \mathrm{kg}^{-1} \mathrm{DMB}\right.$ ) collected from spring 2013 , summer, autumn, winter and spring 2014 and 2015, from the three different regions defined in the current study. Metal levels expressed as mean $( \pm \mathrm{SE})$, at Middle-upper estuary $(n=2)$, Middle-lower estuary $(n=3)$, and Lower estuary $(n=3)$

\begin{tabular}{ccccccc}
\hline \multirow{2}{*}{ Year } & \multirow{2}{*}{ Season } & \multicolumn{2}{c}{ Middle-upper } & \multicolumn{2}{c}{ Middle-lower } & Lower \\
\cline { 3 - 7 } 2013 & Spring & $16.5 \pm 1.5$ & $244 \pm 76.3$ & $9.7 \pm 0.3$ & $19.3 \pm 0.9$ & $4.2 \pm 1.3$ \\
\hline \multirow{2}{*}{2014} & Summer & $23 \pm 1$ & $156 \pm 128.1$ & $9 \pm 0.3$ & $24.8 \pm 3.1$ & $6.6 \pm 1.1$ \\
\cline { 2 - 7 } & Autumn & $26.8 \pm 4.2$ & $67.4 \pm 41.6$ & $9.4 \pm 0.8$ & $42 \pm 15.7$ & $15.5 \pm 3.3$ \\
\cline { 2 - 7 } & Winter & $28.8 \pm 9.5$ & $98 \pm 39.1$ & $12.6 \pm 0.9$ & $30.1 \pm 1.2$ & $8.9 \pm 3.2$ \\
\cline { 2 - 7 } & Spring & $20.5 \pm 2.8$ & $106 \pm 35$ & $13.2 \pm 0.9$ & $10.3 \pm 1.3$ & $4.2 \pm 1.1$ \\
\hline \multirow{2}{*}{2015} & Summer & $22.5 \pm 2.5$ & $83.3 \pm 55.8$ & $14.9 \pm 0.7$ & $19.2 \pm 3$ & $6.5 \pm 1.1$ \\
\cline { 2 - 7 } & Autumn & $23.3 \pm 2$ & $50.6 \pm 28.5$ & $12 \pm 0.8$ & $17.2 \pm 6.6$ & $7.3 \pm 1.1$ \\
\cline { 2 - 7 } & Winter & $17.1 \pm 1.8$ & $73.2 \pm 2.7$ & $15.1 \pm 0.2$ & $35.2 \pm 2.6$ & $9.7 \pm 3$ \\
\cline { 2 - 6 }
\end{tabular}

\subsection{Metal content in seawater}

There was significant spatial variability in Zn concentration in the surface waters $(p<0.05, F=45.623, d f=1)$, with the middle-upper region of the estuary markedly higher than the middle-lower estuary (Table 1). This spatial difference was consistent over time, with no significant seasonal variability. 


\section{Discussion}

$U$. australis appears to be a good biological monitor for zinc in the Derwent estuary, broadly reflecting environmental conditions and providing a better understanding of the biological contamination. Ulva australis accumulated $\mathrm{Zn}$ showing a clear spatial gradient. The highest concentrations in algae were found in areas were the environmental loading was also high, i.e. middle-upper estuary, at Prince of Wales Bay (PWB) and Shag Bay (SB), closest to the Nyrstar Zn smelter and therefore it is not surprising that the metal content detected in $U$. australis was high at these sites. The distribution of metal contamination in Ulva relates well to the patterns of contamination described by the established monitoring or surface waters and sediments (Coughanowr et al., 2015). Consequently, it is reasonable to expect that $U$. australis would provide a realistic and comparable measure of environmental contamination.

Zinc content in algae from the lower estuary was consistently low, and comparable to levels reported for unpolluted systems worldwide, suggesting that this region could act as a reference for the rest of the system. There were clear inter-annual and seasonal differences in $\mathrm{Zn}$ levels in Ulva throughout the estuary. This likely reflects a combination of both the scale of $\mathrm{Zn}$ contamination in the Derwent and the significant remediation efforts to capture industrial inputs over the last few years (Coughanowr et al., 2015). $\mathrm{Zn}$ is the predominant contaminant in the Derwent, and has been established as a suitable proxy for most other heavy metals contaminants (copper (Cu), arsenic (As), and lead (Pb)) (Coughanowr et al., 2015). Zinc has been consistently detected at high concentrations in the water column, sediments, fish and shellfish (Coughanowr et al., 2015). Consequently, evaluating of $\mathrm{Zn}$ levels should provide a good indication of the broader metal contamination in this system.

The temporal differences observed could be due to a number of factors. In a biomonitoring context, it is the differences in the metal loading/ inputs that are important, but temporal differences can also arise as a result of changes in the alga's ability to accumulate metals, that due to physiological status or its environment, both of which could be affected by the timing of sampling. In the current study, $\mathrm{Zn}$ levels in $U$. australis were highest in the most polluted (middle-upper) region of the estuary. In this area the contamination levels are very high and would likely obscure any subtle seasonal or temporal influences.

$\mathrm{Zn}$ content in $U$. australis was greater in spring and summer than other times of the year, which is perhaps not surprising as this is the time when growth/ metabolic rate was highest (in summer) and/ or when the plants were reproductive (in spring). Temporal variability in metal contamination in algae can be related to biological factors such as the growth strategy (annual/ perennial) or to the morphology of the particular species (Stengel et al., 2004). Many studies have shown differences between species, Ulva linza (Formerly
Enteromorpha linza) has been shown to take up metals to a greater extent in spring and summer (Haritonidis and Nikolaidis, 1990), but U. lactuca was found to have the highest Zn content in winter (Brown et al., 1999), (Villares et al. (2002) studied two related Ulva species (U. rigida and $U$. intestinalis) and found that metal content was greatest in autumn/winter, and Haritonidis and Malea (1999) observed maximum metal content in $U$. rigida in autumn. These differences are likely due to changes in plant metabolism, which in turn will be affected by a range of environmental variables such as light and temperature.

Previous research has shown that environmental factors such as salinity can influence Ulva's capacity to take up metals (Ho, 1990; Malea and Haritonidis, 1999a), with levels of metals that generally increase as salinity declines (Mamboya et al., 2009; Villares et al., 2002). There is a reasonably strong salinity gradient in the Derwent estuary, with salinity dropping $10 \mathrm{ppt}$ in surface waters through the middle estuary (from 34-24 ppt), the area most contaminated with $\mathrm{Zn}$ and where the highest levels were detected in $U$. australis. The levels observed in $U$. australis at these sites were clearly elevated, with biological implications for both the plants themselves and the food web. Should the salinity in this region decline (i.e. due to catchment management practices) this could affect the biomonitoring potential of Ulva in two important ways: i) directly - resulting in higher metal levels in the plants and associated increase in biological risk, and ii) indirectly - affecting the temporal and spatial comparability of results in a biomonitoring context. Consequently, it is important to consider salinity when using Ulva in a biomonitoring program.

Using a biomonitoring species such as Ulva can provide an improved understanding of $\mathrm{Zn}$ contamination throughout the estuary over a biologically meaningful timeframe (the growing period of the plant), whilst samples from the water column will only ever provide a snapshot of the concentration at the time of sampling. The results showed that although $U$. australis broadly reflected a similar contamination gradient and pattern to that observed in the water column/ sediment sampling, reflecting the different matrices. Monitoring $U$. australis could provide important information on changes in a bioavailable contamination source over time, something which has been missing in monitoring to date and which could provide an important new approach to evaluate the effect of remediation/ deterioration activities.

Finally, $U$. australis has the added advantage of being both locally abundant and ubiquitous throughout the estuary. Previous studies have suggested that local species are generally the most suitable for biomonitoring (Rainbow, 2006; Phillips and Rainbow, 1994), and that cosmopolitan, widely distributed (O'Leary and Breen, 1997) or abundant (Amado Filho et al., 1999) species are to be preferred. Currently seaweeds are not included in the Derwent Estuary monitoring program. Adopting $U$. australis as an indicator in this program, in conjunction with seawater and sediment monitoring, would provide 
another line of evidence with which to assess changes (improvement/ deterioration) in the "biological" condition of this metal-impacted system.

\section{Conclusion}

There was a strong spatial gradient of metal contamination within the estuary, with the middle-upper estuary having an extremely high level of $\mathrm{Zn}$ pollution. This spatial variability was clearly reflected in Ulva australis. There was evidence of seasonal differences in the metal content in Ulva, with the highest levels observed in spring and summer. Environmental conditions, particularly salinity, may affect results and therefore should be treated with caution where there are marked changes in salinity. Biological factors (e.g. growth or morphology) also affected metal content in $U$. australis with levels of contamination being influenced by the key biological processes/ phenology. However, it is clear that $U$. australis can play a valuable role as biomonitoing species, and can help improve our understanding of the potential risks and changes (improvements and deteriorations) in metal contaminated systems.

\section{Acknowledgments}

The authors would like to acknowledge to the Derwent Estuary Program (DEP) for providing environmental data. To Tania Mendo and Malinda Auluck for their support on the field, to Rafael León for statistical advice, and Gerry Kraft from the Tasmanian Herbarium for the taxonomy identification of Ulva specimens. This research was funding by The Holsworth Wildlife Research Endowment (M0021673 HWRE) and BECAS Chile, CONICYT-CHILE.

\section{References}

Amado Filho G.M., Andrade L.R., Karez C.S., Farina M. and Pfeiffer W.C. (1999), Brown algae species as biomonitors of $\mathrm{Zn}$ and $\mathrm{Cd}$ at Sepetiba Bay, Rio de Janeiro, Brazil, Marine Environmental Research, 48, 212-224, doi:10.1016/S01411136(99)00042-2.

Bloom H. and Ayling G.M. (1977), Heavy metals in the Derwent Estuary, Environmental Geology, 2, 3-22, doi:10.1007/BF02430661.

Brown M.T., Hodgkinson W.M. and Hurd C.L. (1999), Spatial and temporal variations in the copper and zinc concentrations of two green seaweeds from Otago Habour, New Zealand, Marine Environmental Research, 47, 175-184, doi:10.1016/S0141-1136(98)00113-5.

Bryan G.W. and Langston W.J. (1992), Bioavailability, accumulation and effects of heavy metals in sediments with special reference to United Kingdom estuaries: A review, Environmental Pollution, 76(2), 89-131, doi:10.1016/02697491(92)90099-V.

Bryan G.W., Langston W.J., Hummerstone L.G. and Burt G.R. (1985), A guide to the assessment of heavy-metal contamination in estuarine using biological indicators, 4, 93.

Campbell I.C. (2002), Biological monitoring and assessment using invertebrates. In: Burden F., McKelvie I., Fostner U. and Guenther A. (Eds.), Environmental Monitoring Handbook. MacGraw-Hill Handbook Series, New York, 1100 pp.

Conti M.E., Tudino M.B., Muse J.O. and Cecchetti G. (2002), Biomonitoring of heavy metals and their species in the marine environment: the contribution of atomic absorption spectroscopy and inductively coupled plasma spectroscopy, Trends in Applied Spectroscopy, 4, 295-324.

Coughanowr C., Whitehead S., Whitehead J., Einoder L. and Taylor U. (2015), State of Derwent: a review of environmental data from 2009 to 2014, Derwent Estuary Program.

Dix T.G., Martin A., Ayling G.M., Wilson K.C. and Ratkowsky D.A. (1975), Sand Flathead (Platycephalus bassensis) an indicator species for mercury pollution in Tasmanian waters. Marine Pollution Bulletin, 6(9), 142-144, doi:10.1016/0025326X(75)90172-1.

Eustace J.J. (1974), Zinc, cadmium, copper and manganese in species of finfish and shellfish Caught in the Derwent Estuary, Tasmania, Australian Journal of Marine and Freshwater Research, 25, 209-220, doi:10.1071/MF9740209.

Farias D.R., Hurd C.L., Eriksen R.S., Simioni C., Schmidt E.C., Bouzon Z.L. and Macleod C.K. (2017), In situ assessment of Ulva australis as a monitoring and management tool for metal pollution. Journal of Applied Phycology, doi:10.1007/s10811-017-1073-y.

Favero N., Cattalini F., Bertaggia D. and Albergoni V. (1996), Metal accumulation in a biological indicator (Ulva rigida) from the Lagoon of Venice (Italy), Archives Environment Contamination Toxicology, 31, 9-18, doi:10.1007/BF00203902.

Haritonidis S. and Malea P. (1999), Bioaccumulation of metals by the green alga Ulva rigida from Thermaikos Gulf, Greece, Environmental Pollution, 104(3), 365-372, doi: 10.1016/S0269-7491(98)00192-4.

Haritonidis S. and Nikolaidis G. (1990), Cd and Zn uptake in macrophyceae from Greek coasts. Biology Metals, 2, 235-238, doi:10.1007/BF01141366.

Ho Y. (1984), Zn and Cu concentrations in Ascophullum nodosum and Fucus vesiculosus (Phaeophyta, Fucales) after transplantation to an estuary contaminated with mine wastes, Conservation \& Recycling, 7(2-4), 329-337, doi:10.1016/0361-3658(84)90031-6.

Ho Y. (1990), Ulva lactuca as bioindicator of metal contamination in intertidal waters in Hong Kong, Hydrobiologia, 203, 73-81, doi:10.1007/BF00005615.

Holt E.A. and Miller S.W. (2011), Bioindicators: Using organism to measure environmental impacts, Nature Education Knowledge, 3(10), 1-10.

Kennish M.J. (2002), Environmental threats and environmental future of estuaries, Environmental Conservation, 29(01), 78107, doi:10.1017/s0376892902000061

Langolis D., Cooper R.J., Clark N.H. and Ratkowsky D.A. (1987), The effect off a mercury containment programme at a zinc smelting plant on the mercury content of sand flathead in the Derwent estuary. Marine Pollution Bulletin, 18(2), 67-70, doi:10.1016/0025-326X(87)90569-8.

Lenth R.V. and Hervé M. (2015), Ismeans: Leasy-Squares Means. R package version 2.16 .

Lionetto M.G., Caricato R., Giordano M.E., Erroi E. and Schettino T. (2012), Carbonic anhydrase as pollution biomarker: an ancient enzyme with a new use. International Journal of Environmental Research of Public Health, 9(11), 3965-3977, doi:10.3390/ijerph9113965. 
Malea P. and Haritonidis S. (1999a), Metal content in Enteromorpha linza (Linnaeus) in Thermaikos Gulf (Greece), Hydrobiologia, 394, 103-112, doi: 10.1023/ A:1003517606630.

Malea P. and Haritonidis S. (1999b), Seasonal accumulation of metals by red alga Gracilaria verrucosa (Huds.) Papens. from Thermaikos Gulf, Greece, Journal of Applied Phycology, 11, 503-509, doi:10.1023/A:1008168631508.

Malea P. and Haritonidis S. (2000), Use of the green alga Ulva rigida C. Agardh as an indicator species to reassess metal pollution in the Thermaikos Gulf, Greece, after 13 years, Journal of Applied Phycology, 12, 169-176, doi:10.1023/A:1008136320459.

Malea P., Haritonidis S. and Kevrekidis T. (1995), Metal content of some green and brown seaweeds from Antikyra Gulf (Greece), Hydrobiologia, 310, 19-31. doi:10.1007/ BF00008180.

Mamboya F., Lyimo T.J., Landberg T. and Björk M. (2009), Influence of combined changes in salinity and copper modulation on growth and copper uptake in the tropical green macroalga Ulva reticulata. Estuarine, Coastal and Shelf Science, 84(3), 326-330, doi:10.1016/j.ecss.2009.03.034.

O'Leary C. and Breen J. (1997), Metal levels in seven species of mollusc and in seaweeds from the Shannon Estuary. Biology and Environment: Proceeding of the Royal Irish Academy, 97B(2), 121-132.

Phillips D. and Rainbow P. (1994), Biomonitoring of Trace Aquatic Contaminants, Chapman \& Hall, London. 371 pp.

R Core Team (2013), R: A language and environment for statistical computing, $R$ Foundation for Statistical Computing. http://www.R-project.org/.

Rainbow P.S. (1993), Biomonitoring of Marine Heavy Metal Pollution and its Applications in Hong Kong Waters. Hong Kong University Press, Hong Kong. 235-250 pp.

Rainbow P.S. (1995), Biomonitoring of heavy metal availability in the marine environment, Marine Pollution Bulletin, 31(4-12), 183-192, doi:10.1016/0025-326X(95)00116-5.

Rainbow P.S. (2006), Biomonitoring of trace metals in estuarine and marine environments, Australian Journal of Ecotoxicology, 12, 107-122.

Rainbow P.S. and Phillips D.J.H. (1993), Cosmopolitan biomonitors of trace metals. Marine Pollution Bulletin, 26(11), 593-601, doi:10.1016/0025-326X(93)90497-8.

Ratkowsky D.A., Dix T.G. and Wilson K.C. (1975), Mercury in fish in the Derwent estuary, Tasmania, and its relation to the position of the fish in the food chain. Australian Journal of Marine and Freshwater Research, 26(2), 223-231, doi:10.1071/MF9750223.

Riget F., Johansen P. and Asmund G. (1995), Natural seasonal variation of cadmiun, copper, lead and zinc in brown seaweed (Fucus vesiculosus). Marine Pollution Bulletin, 30(6), 409-413, doi:10.1016/0025-326X(95)99847-W.

Stengel D.B., Macken A., Morrison L. and Morley N. (2004), Zinc concentrations in marine macroalgae and a lichen from western Ireland in relation to phylogenetic grouping, habitat and morphology, Marine Pollution Bulletin, 48(9-10), :902909, doi:10.1016/j.marpolbul.2003.11.014.

Verdouw J.J., Macleod C.K., Nowak B.F. and Lyle J.M. (2010), Implications of age, size and region on mercury contamination in estuarine fish species. Water, Air,
\& Soil Pollution, 214(1-4), 297-306, doi:10.1007/11270-0100424-y.

Villares R., Puente X. and Carballeira A. (2002), Seasonal variation and background levels of heavy metals in two green seaweeds. Environmental Pollution, 119(1), 79-90, doi:10.1016/S0269-7491(01)00322-0.

Whitehead J., Coughanowr C., Agius J., Chrispijn J., Taylor U. and Wells F. (2010), State of the Derwent Estuary 2009: A Review of Pollution Sources, Loads and Environmental Quality Data from 2003-2009 (trans: Derwent Estuary Program D). Derwent Estuary Program, Hobart, Tasmania, Australia.

Wood J.M., Horwitz P. and Cox H. (1992), Levels of heavy metals in dated sediments from Lindisfarne Bay, Derwent Estuary, Tasmania. The Science of the total environment, 125, 253262, doi:10.1016/0048-9697(92)90395-9.

Zhou Q., Zhang J., Fu J., Shi J. and Jiang G. (2008), Biomonitoring: An appealing tool for assessment of metal pollution in the aquatic ecosystem. Analytica Chimica Acta, 606(2), 135-150, doi:10.1016/j.aca.2007.11.018. 